\title{
Attitudes of administrative decision-makers towards nature-based solutions for flood risk management in Germany
}

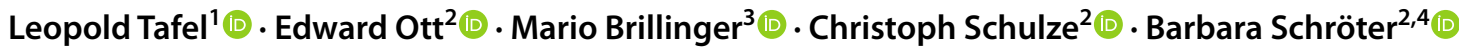

Received: 27 May 2021 / Accepted: 23 November 2021 / Published online: 17 December 2021

(c) The Author(s) 2021

\begin{abstract}
Over the last two decades, alternative and holistic concepts, such as Nature-based Solutions (NbS) were introduced and adopted by policy-makers, including to the field of flood protection, thereby causing a paradigm shift towards flood risk management. The inclusion of natural water retention measures (NWRM) such as dike relocation and floodplain restoration into the German guidelines for flood protection institutionalized the new concepts in Germany. Whereas small scale NbS and the affected population have already been subject to thorough scientific research, large-scale $\mathrm{NbS}$ and the decisionmakers assigned with the measure's implementation have yet to be studied. How do administrative decision-makers perceive the new approach and measures? Are there particular attitudes among the decision-makers regarding NbS? Which aspects of implementing large-scale $\mathrm{NbS}$ influence possible attitudes? Which hurdles do decision-makers concern for the implementation of the new concepts? This paper investigates these questions on the example of dike relocation and floodplain restoration using Q-methodology with administrative decision-makers of flood protection authorities in the German state of Saxony-Anhalt. The consecutive statistical analysis unveiled three significant viewpoints among the decision-makers. The viewpoints/attitudes were classified as 1 . The Convinced, 2. The Concerned and, 3. The Evaluators, defined by varying and individual concerns on the implementation of dike relocation and floodplain restoration. Hereby, this study delivers insights on large-scale $\mathrm{NbS}$ as well as on the issues of their implementation.
\end{abstract}

Keywords Q-methodology · Dike relocation · Floodplain restoration · Natural water retention measures · Saxony-Anhalt · Authorities

\section{Introduction}

In the last decades, a paradigm shift took place in Germany and Europe from flood protection to flood risk management (Hartmann and Albrecht 2014; Thomas and Knüppe 2016). Official policy treats both technical measures and Natural

Handled by Maike Hamann, Stellenbosch University, South Africa.

Leopold Tafel

leopold.tafel@gmail.com

Edward Ott

edward.ott@zalf.de

Mario Brillinger

Mario.Brillinger@ruhr-uni-bochum.de

Christoph Schulze

christoph.schulze@zalf.de

Barbara Schröter

barbara.schroeter@zalf.de
Water Retention Measures (NWRMs) as equally important for flood risk management (Dworak and Görlach 2005; Patt and Jüpner 2020). Recently, the concept of Nature-based solutions (NbS) has been associated with NWRM and green infrastructure (GI) (Moosavi et al. 2021). Despite the ample evidence and policy-makers' acknowledgment of the multiple benefits of $\mathrm{NbS}$ for flood risk management (Grossmann et al. 2010; Schindler et al. 2014; Hartmann et al. 2019) and

1 Albrecht Daniel Thaer-Institute of Agricultural and Horticultural Sciences, Humboldt-Universität zu Berlin, Invalidenstraße 42, 10099 Berlin, Germany

2 Leibniz-Centre for Agricultural Landscape Research, Working Group "Governance of Ecosystem Services", Eberswalder Str. 84, 15374 Müncheberg, Germany

3 Institute of Geography, Ruhr University Bochum, Universitätsstraße 150, 44805 Bochum, Germany

4 Centre for Sustainability Studies, Lund University, Lund, Sweden 
for creating more resilient societies (Grossmann et al. 2010; Da Silva and Wheeler 2017; Hansen et al. 2019), implementation is still slow. The knowledge on the role that decisionmakers' attitudes play in explaining this implementation-gap for NWRMs in flood risk management is still limited. Therefore, this paper aims to identify public sector decision-makers' attitudes in the German state of Saxony-Anhalt toward $\mathrm{NbS}$ for flood prevention.

For this study, we define decision-makers as individuals with responsibility for a team and topic within their authority. Based on our previous work, we understand $\mathrm{NbS}$ as "actions that (i) alleviate a well-defined societal challenge, (ii) utilize ecosystem processes of spatial, blue and green infrastructure networks, and (iii) are embedded within viable governance or business models for implementation" (Albert et al. 2019). The International Union for Conservation of Nature (IUCN) stresses the importance of $\mathrm{NbS}$ for biodiversity conservation defining $\mathrm{NbS}$ as "actions to protect, sustainably manage and restore natural and modified ecosystems that address societal challenges effectively and adaptively, simultaneously providing human well-being and biodiversity benefits" (Cohen-Shacham et al. 2016). The European Commission, in contrast, provides a more general definition and defines $\mathrm{NbS}$ as "actions which are inspired by, supported by or copied from nature" (European Commission 2015). Typical large-scale NbS are floodplain restorations and management and the reclamation of natural retention areas through dike relocations. In contrast to $\mathrm{NbS}$, technical or "gray" solutions are classical one-purpose engineering measures, such as reservoirs, dikes, floodwalls, or drainage systems (Hartmann et al. 2019).

Researchers expect that climate change will sharply increase flood risk in terms of potential damages and the number of people affected in several European regions by the end of the twenty-first century (Rojas et al. 2013; EEA 2017; Szewczyk et al. 2018; Hosseinzadehtalaei et al. 2020). Floods are part of rivers' natural fluvial dynamics and are a fundamental driving force of ecosystem processes and services (Shafroth et al. 2010). In Europe, river floods are among the most dangerous natural hazards, responsible for billions of Euros in annual economic damages (EEA 2010). These damages are exacerbated by anthropogenic activities (Merz et al. 2012; Rojas et al. 2013; Jongman et al. 2014). Dikes and river-straightening, agricultural land use, and surface sealing increase flood risk, the loss of a majority of floodplains, and the degradation of ecosystem services in river landscapes (Merz et al. 2012; Gilvear et al. 2013).

To mitigate these effects and prevent floods, Germany and other EU countries aim to increase and improve retention areas through dike relocation and floodplain restoration projects (European Commission 2014; BMU 2015; MULE $2020 \mathrm{~b}$ ). The extreme flood events of the last decades accelerated this process (e.g., 1997, 2002, 2013) by making flood management a priority of the affected German states' political agendas and their water authorities (BMU 2015; EEA 2017; MULE 2020b). These events have shown authorities and the public that dikes cannot guarantee absolute protection, but under certain conditions even promote the potential for damage in flood-prone areas (Kok and Grossmann 2010; Di Baldassarre et al. 2018).

Considering that two-thirds of the former 15,000 square kilometers of floodplains in Germany are disconnected from river dynamics (BMU 2015), the current efforts to implement dike relocations to regain retention space seem negligible. Despite hydrological studies demonstrating the effectiveness of dike relocations (Schwaller 2006; Alexy 2013; Faulhaber 2013; Heinzelmann et al. 2016) and the political support through national programs, these measures are only slowly picked up and considered for flood prevention purposes. As of today dike relocation projects are still exceptions in German states' flood risk management plans (Brillinger et al. 2020). Knowledge about barriers for implementation of natural flood management approaches exists (Sarabi et al. 2019; Solheim et al. 2021). However, systematic knowledge of decision-makers' views and expectations toward such measures and their impact on implementation is still understudied.

Venkataramanan et al. (2020) point out the need to systematically assess the "human dimensions" for using GI for flood management. Their review analyzes studies dealing with knowledge, attitudes, intentions, and behavior of using GI in flood management in the urban context. The review finds that the willingness to implement GI varies and strongly depends on the context. The analyzed studies on attitudes cover functional, aesthetic, health, safety, conservation, financial, and cultural values of different GI measures in the urban context. Several studies found that respondents doubt GI measures' potential to effectively prevent flooding (Kati and Jari 2016; Meng et al. 2018). Concerns among decision-makers about the effectiveness of $\mathrm{NbS}$ is a recurring theme in recent studies (Sarabi et al. 2019; Bark et al. 2021; Solheim et al. 2021). Most of the cited studies in this paragraph focus on the urban context, but first studies exist that illustrate the effectiveness of $\mathrm{NbS}$ such as wetlands on larger landscape scales (Thorslund 2017). The landscape and river context differs significantly from the urban context in its spatial dimensions, ecological dynamics, and required flood management approaches. However, decision-makers' behavioral patterns, attitudes, and institutional, technical, economic, and stakeholder-related aspects may be comparable (Solheim et al. 2021).

Several studies highlight these aspects and their impact on the implementation of NbS (Guerrin, 2015; van Buuren et al. 2018; Waylen et al. 2018; Han and Kuhlicke 2019; Wells et al. 2020; Bark et al. 2021; Solheim et al. 2021). In a comprehensive analysis of case studies, Solheim et al. (2021) found that 


\section{Stimme nicht zu}

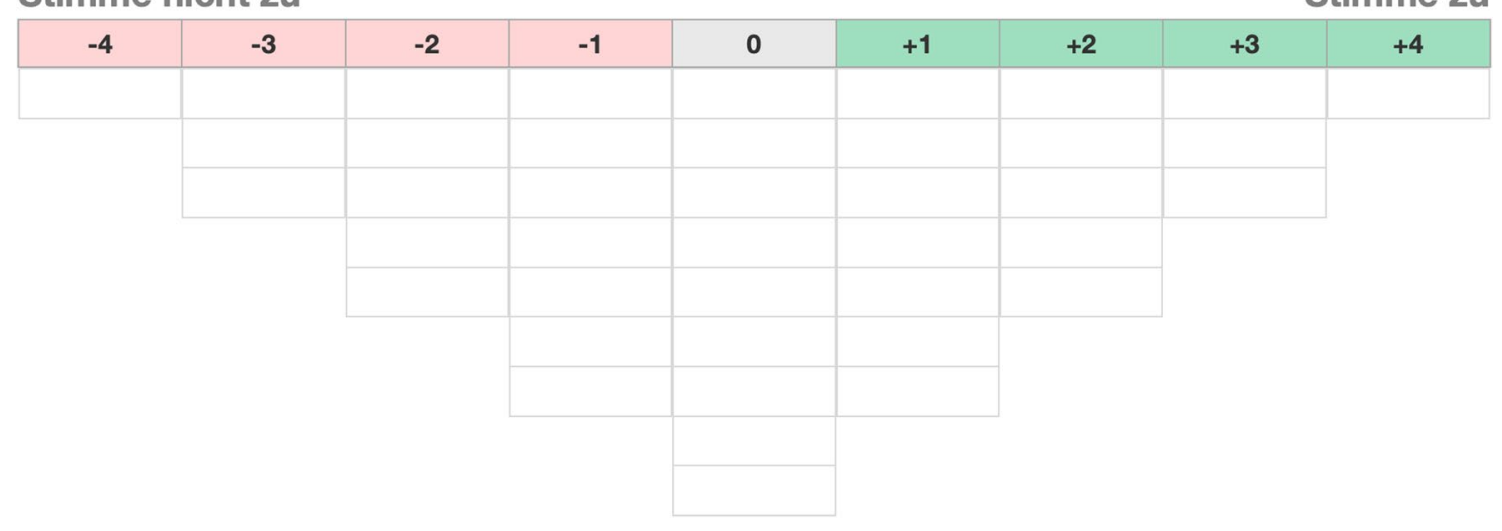

Fig. 1 The "Q-grid" used for this study, consisting of 41 tiles

the lack of political will and long-term commitment paired with a lack of public support, risk aversion, resistance to change, uncertainty in $\mathrm{NbS}$ effectiveness, and perceived high cost can lead to implementation failure in projects dedicated to reducing hydro-meteorological hazards. The basis of many of these barriers is the skepticism caused by a lack of knowledge about $\mathrm{NbS}$ among authorities, landowners, politicians, and contractors in the construction industry. Mainly, knowledge of NbS' ability to deliver multiple benefits is lacking in these stakeholder groups (Venkataramanan et al. 2020; Wells et al. 2020; Solheim et al. 2021). The extent of the knowledge gap differs between stakeholder groups. For practitioners in the UK, Wells et al. (2020) found that their skepticism is not necessarily related to a lack of knowledge about natural flood management measures but related to their engineering background and unfamiliarity with these approaches.

As the role of decision-makers' attitudes toward dike relocation measures for flood prevention still has not been systematically assessed, this paper contributes to this body of literature. We focus our study on decision-makers in water authorities in the German state of Saxony-Anhalt and shed light on decision-makers' attitudes toward dike relocations with floodplain restoration, also referred to as "the measures" throughout this paper. We use Q-methodology to explore decision-makers' viewpoints regarding the implementation of the combined measures for flood risk management. Additionally, we analyze which aspects decisionmakers deem essential for implementing dike relocations and floodplain restorations.

\section{Materials and methods}

\section{Q-methodology}

Q-methodology originates from the field of psychology and is now applied to a variety of other domains of research as well (Brown 1980; Zabala et al. 2018). In the field of water retention, for instance, Q-methodology has been used to analyze the views of social and environmental researchers on dam development in Latin America (Schulz and Adams 2021) or the vulnerability of stakeholders reliant on water-based ecosystem services derived from the Shoshone National Forest in Wyoming (Armatas et al. 2017). The methodology is primarily used to reveal social viewpoints on a specific topic among stakeholders (Watts and Stenner 2012). Thereby, Q-methodology combines advantages of qualitative and quantitative research approaches (Brown 1993). The method has been used to investigate patterns in stakeholder opinions on issues such as animal intelligence, ecological economics, forest management, environmental policy and decision-making (Webler et al. 2009). In terms of investigating conservation goals, Q-methodology has been applied to address conflict, devise management alternatives, understand policy acceptability, and critically reflect on the values that implicitly influence research and practice (Zabala et al. 2018), making it a suitable tool to investigate decision-makers' attitudes in flood risk management.

Q-methodology is based on an interview format, in which researchers present stakeholders with pre-defined opinion statements concerning a topic. Participants agree or disagree with the statements by sorting them into a forced-choice distribution grid along a scale (see Fig. 1). The individual statement allocations resulting from this process are referred to as "Q-sorts" (Brown 1993; Watts and Stenner 2012). In the end, researchers are able to compare statement allocations and derive different attitude profiles from common sorting patterns. For a successful Q-study it is crucial to clearly define opinion statements (concourse and Q-set), select relevant stakeholders (P-set), and determine the correct interview format (Watts and Stenner 2012; Zabala et al. 2018). In the remainder of this section, we present the design of our undertaken Q-study starting with case study and participants 
Fig. 2 Dike relocations in Saxony-Anhalt, Germany. * Note: The figure shows 23 measures; however, for one of the measures in the "long-term realization" phase, it is currently still unclear whether it will be implemented as a dike relocation or as a polder. For that reason, we speak of only 22 dike relocations in the text

\section{Dike relocation measures in Saxony-Anhalt, Germany}

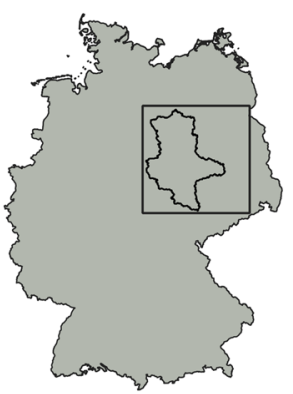

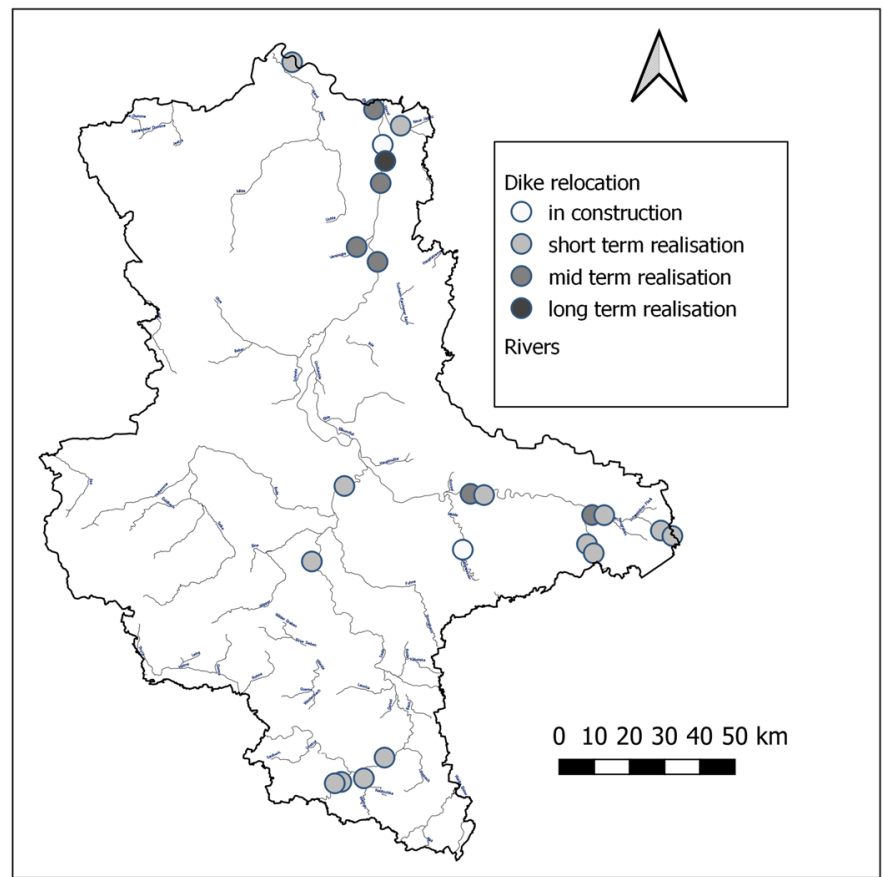

(BMUB 2015; Koenzen et al. 2021). These figures show that Saxony-Anhalt is a pioneer in implementing dike relocation with floodplain restoration in Germany. It is therefore likely that decision-makers in Saxony-Anhalt are familiar with the concept and can provide expert opinions.

Saxony-Anhalt has assigned responsibility for flood risk management to the following authorities:

1. The Ministry of Environment, Agriculture, and Energy (MULE) as the highest water authority;

2. The State Administration Office (Landesverwaltungsamt) as the upper water authority;

3. The counties and independent cities as lower water authorities; and

4. The Saxony-Anhalt State Office for Flood Protection and Water Management (LHW) as the implementing authority (Sachsen-Anhalt 2011b).

The State Administration Office has legal supervision over dike relocations whereas the LHW develops and maintains the state's watercourses (Sachsen-Anhalt 2011a). The LHW is a subordinate agency of the MULE. Additionally, we included the biosphere reserve administration "Mittelelbe" as another subordinate agency of the MULE to the list of relevant authorities. An online search for decision-makers within these authorities turned up 75 matches. All were contacted via email and asked to participate in the study. Those who did not respond were called a few days later. Fifteen interviews were scheduled, resulting in 15 Q-sorts. The 15 
participants work at the following authorities: Biosphere Reserve Administration (1), Lower Authorities (6), MULE (2), LHW (6).

\section{Concourse}

The concourse is central to Q-methodology. It comprises statements that ideally contain expressions of all possible perspectives held on the topic in question. These statements can be collected by analyzing literature and media. However, it is considered more efficient and precise to perform interviews with informed individuals to gather relevant statements. Interviews also deliver valuable subjective insights (Webler et al. 2009; Watts and Stenner 2012). Therefore, we conducted 21 semi-structured interviews about dike relocation and flood plain restoration with flood management experts in 2018 and 2019. These interviews served as the source material for a pre-selection of 271 statements.

\section{Q-sample (Q-set)}

The Q-set is a representative sample of the concoursea whole set of possible expressions on the topic gathered from all possible points of view (Zabala 2014). Following a structured approach, we narrowed down the concourse by consolidating statements of similar meaning or argumentation. This process allowed us to identify recurring themes within the remaining statements and order them into three categories: 1. Financing/Efficiency, 2. Implementation Challenges and 3. Objectives and Outcomes. Condensing and rephrasing the categorized statements further produced the final selection of 41 statements, the Q-set. Ten out of the 41 statements related to financing aspects and the measures' economic effectiveness. Another ten focused on challenges associated with the measures' implementation, such as availability of land, consent within the population, and timeconsuming planning procedures. Twenty-one statements refer to the measures' effects for flood protection, landscape aesthetics, ecological impact, and common objectives which the measures are meant to fulfill, such as creating synergies between the water framework and the floods directive as well as providing benefits for nature and people's well-being.

To test the quality and comprehensiveness of the selected statements, three trial interviews were conducted. The trials were undertaken with flood protection experts of the Brandenburg Ministry of Agriculture, Environment and Climate Protection, the Hessen Regional Council Gießen, and the North Rhineland-Palatinate Structural and Approval Directorate. Individual statements were edited for better comprehension and clarity after the trials.

\section{Q-sorting process}

Participants order the provided statements during the Q-sort. First, we asked participants to stack the 41 statements into three piles: disagree, neutral and agree. Next, the participants sorted the statements into a grid of 41 cells (see Fig. 1), giving a value to each statement ranging from -4 (disagree) to +4 (agree).

The bell-shaped grid forced participants to prioritize a small number of statements over others and made finished sorts comparable to one another. The Q-sort was set up online with an HTML5 Q-sorting tool (Aproxima et al. $2020)^{1,2}$

\section{Results}

We analyzed the data, consisting of 15 Q-sorts, with the 'qmethod' package. ${ }^{3}$

The flagging of Q-sorts allowed us to significantly link 13 of the 15 Q-sorts to one of the three extracted factors (see Table 1). Based on these 13 included Q-sorts, three-factor arrays, i.e., exemplary Q-sorts of the factors (see Table 3), were calculated. These exemplary Q-sorts are a simplified representation of the factors' opinion spectrum and depict how the average person loading onto that factor sorted the statements.

\footnotetext{
1 The software code is available for free on GitHub (https://github. com/aproxima/htmlq\#htmlq).

${ }^{2}$ Participants simultaneously explained their choices over the phone as they used the online tool.

${ }^{3}$ https://github.com/aiorazabala/qmethod accessed: October 2020. for R by Zabala (2014). The Q-sorts were intercorrelated using Pearson correlation to explore commonalities among the sorting patterns. Then we applied Principal Component Analysis (PCA) to reduce the dimension of the data and to identify shared viewpoints of the participants. We extracted three shared viewpoints, or factors, as they are called in Q-terminology. A resulting metric from the PCA are the socalled "factor loadings" that indicate the correlation of a Q-sort with an underlying factor. In several instances the Q-sorts loaded highly on multiple factors. Consequently, we applied varimax rotation to maximize the factor loadings of individuals Q-sorts and variance explained by individual factors. The resulting rotated factor loadings can be found in Table 1. The decision of how many factors (viewpoints) to extract from the data was subject to statistically objective criteria such as percentage of variance explained per factor (Cattell 1966), Kaiser-Guttman Criterion (Guttman 1954), Humphrey's Rule (Sandon and Fruchter 1956) and number of flagged Q-sorts per factor (Brown 1980) (see Tables 1 and 2). A Q-sort is flagged when a Q-sort's factor loading is sufficiently high and factor loadings for that Q-sort are significantly different. To test whether two factor loadings are significantly different from each other, we computed the standard error of the differences between the factor loadings. When testing the dataset for three underlying factors, all statistical criteria were ful-
} filled. 
Table 1 The rotated factor loadings with Q-sorts as rows and factors as columns

\begin{tabular}{llcc}
\hline & \multicolumn{3}{l}{ Rotated Factor Loadings } \\
\cline { 2 - 4 } & Factor 1 & Factor 2 & Factor 3 \\
\hline Participant 1 & $0.66^{*}$ & 0.32 & 0.45 \\
Participant 2 & $0.72^{*}$ & 0.03 & 0.17 \\
Participant 3 & 0.01 & 0.04 & $0.86^{*}$ \\
Participant 4 & 0.38 & 0.46 & 0.52 \\
Participant 5 & $0.61^{*}$ & 0.23 & 0.04 \\
Participant 6 & 0.18 & $0.55^{*}$ & 0.34 \\
Participant 7 & $0.73^{*}$ & 0.31 & -0.06 \\
Participant 8 & $0.56^{*}$ & 0.25 & 0.18 \\
Participant 9 & $0.66^{*}$ & -0.07 & 0.51 \\
Participant 10 & 0.53 & 0.24 & 0.48 \\
Participant 11 & 0.27 & $0.81^{*}$ & 0.03 \\
Participant 12 & $0.65^{*}$ & 0.33 & 0.28 \\
Participant 13 & 0.43 & 0.43 & $0.62^{*}$ \\
Participant 14 & 0.29 & 0.48 & 0.42 \\
Participant 15 & 0.11 & $0.91^{*}$ & 0.06 \\
\hline
\end{tabular}

Note. This study's standard error equals $\frac{1}{\sqrt{N}}=\frac{1}{\sqrt{41}}=0.156$, where $N$ equals the number of statements. According to Humphrey's rule the cross-product of a factors two highest factor loadings has to be greater than twice the standard error for a factor to be significant. Thus, greater than $\frac{2}{\sqrt{41}}=0.312$ for this study. The cross-product of the two highest factor loadings of factor 1 is 0.53 (or $0.73 \times 0.72$ ), 0.74 (or $0.81 \times 0.91$ ) for factor 2 , and 0.53 (or $0.86 \times 0.62$ ) for factor 3 . Since all factors cross-products are greater than 0.312 , all three factors extracted are significant (Sandon and Fruchter, 1956)

*The most representative Q-sorts for each factor are flagged, meaning that only these Q-sorts are used for subsequent calculations to obtain more distinguishable perspectives (Zabala, 2014)

Each factor represents a generalized viewpoint on dike relocation with flood plain restoration for flood prevention held by like-minded participants. The three viewpoints were classified as Viewpoint 1. The Convinced, Viewpoint 2. The Concerned and, Viewpoint 3. The Evaluators.

\section{Viewpoint 1: The Convinced}

Seven of the 15 participants are significantly associated with the viewpoint of The Convinced. This viewpoint has an eigenvalue of 3.8 and explains $25.60 \%$ of the study variance. Decision-makers of the following authorities loaded into this factor: Biosphere Reserve Administration (1); Lower Authorities (1); MULE (2); LHW (3). The Convinced are particularly distinguished by statements $5,7,10,15,22$, and 41.

The Convinced think the measures should be implemented even if costs are high $(\# 5:+3)$. They clearly prefer these measures over extending or refurbishing existing dikes (\#7: -2). "I need the space anyway, and dike relocation shortens [the dike], which makes it actually cheaper and therefore, statement \#7 is simply wrong," argues Participant 7 (LHW). They justify this attitude by emphasizing that the measures improve overall ecosystem resilience $(\# 21:+4)$ and provide synergies compared to purely technical flood protection (\#38: +3). “[...] with a floodplain, vegetation, and an increase in area and species, the resilience (of the ecosystem) to environmental pollution is simply greater," further elaborates Participant 7 (LHW). Some even argue that "the measures should always be preferred [over other measures], because this is the natural course of the river. In my county, it is just farmland protected by the dikes. It would be wise to relocate the dikes to generate new retention space for the river," according to Participant 8 (Lower Authority) (\#19: +1).

With respect to hydraulics, The Convinced do not think that large trees and bushes pose a problem in retention areas (\#27: -4). Furthermore, "the measures work well in large catchment areas," says Participant 12 (LHW) (\#30: - 3). The Convinced believe in the effectiveness of the measures for flood protection (\#24: -3 ). They also think that acceptance among the affected populations is higher for dike reinforcement than for dike relocation with floodplain restoration (\#41: +1). "People prefer the status quo. Farmers,
Table 2 The number of flagged Q-sorts, the composite reliability, and the standard error of factor scores

\begin{tabular}{|c|c|c|c|c|c|c|}
\hline & \multicolumn{6}{|c|}{ General factor characteristics } \\
\hline & $\begin{array}{l}\text { Average relative } \\
\text { coefficient }\end{array}$ & $\begin{array}{l}\text { Flagged } \\
\text { sorts }^{\text {a }}\end{array}$ & Eigenvalues $^{\mathrm{B}}$ & $\begin{array}{l}\text { Variance } \\
\text { explained }\end{array}$ & Reliability & $\begin{array}{l}\text { Standard error } \\
\text { of factor scores }\end{array}$ \\
\hline Factor 1 & 0.8 & 7 & 3.84 & 25.60 & 0.97 & 0.19 \\
\hline Factor 2 & 0.8 & 3 & 2.90 & 19.35 & 0.92 & 0.28 \\
\hline Factor 3 & 0.8 & 2 & 2.53 & 16.86 & 0.89 & 0.33 \\
\hline
\end{tabular}

${ }^{a}$ The number of flagged Q-sorts per factor should be $\geq 2$ (Brown 1980). The most representative Q-sorts for each factor are flagged, meaning that only these Q-sorts are used for subsequent calculations in order to obtain more distinguishable perspectives

bEigenvalues or the "Kaiser-Guttman Criterium" should be $>1$ per factor (Guttman 1954)

${ }^{\mathrm{c}}$ The variance explained per factor should be greater than $10 \%$ (Cattell 1966)

${ }^{\mathrm{d}}$ The combined variance explained of all extracted factors must be greater than $35 \%$ 
Table 3 The Factor Arrays of a selected number of factors, representing one perspective each

Statements

Factor scores

(Viewpoints)

Category 1: financing/efficiency:

1. In the long term, the maintenance costs of these measures are lower than purely technical flood protection

2. There is a lack of reliable data and figures to evaluate the economic efficiency of these measures

3. The financing of such measures is not an issue

4. The state lacks the money to implement such measures

5. Even if the costs of the measures are high, it makes sense to implement them

6. The environmental and resource costs should be taken into account for a cost-benefit analysis of the measures

7. Extension/refurbishment of the existing dike routes are preferable, as they are more cost-effective

8. The advantages of the measures that go beyond flood protection provide important arguments for their financing

9. Such measures can be financed relatively easily, through existing support programs

10. Flood protection should be as cheap as possible

\section{Category 2: Implementation Challenges}

11. If the required area has multiple owners, such measures are hardly feasible

12. For the implementation of such measures, it is crucial that those affected are actively involved

13. Affected municipalities/communities have little interest in such measures

14. The main problem with such measures is the availability of land

15. The affected population welcomes such measures

16. The current financing instruments are not sufficient to solve the problem of land availability for such measures

17. If operators of hydropower and sewage treatment plants are affected, such measures cannot be implemented

18. The implementation of such measures is largely dependent on the commitment of dedicated individuals

19. Such measures should be preferred over other flood protection measures

20. The implementation of these measures is much more time-consuming than the restoration of dike routes

\section{Category 3: Objectives and outcomes}

21. The measures improve the resilience of the ecological system in every regard

22. The possible pollutants in river sediments pose a problem with such measures

23. There is a lack of reliable data and figures to evaluate the ecological impact of the measures

24. The measures do not provide effective flood protection

25. The measures improve the flood situation for downstream riparians

26. The measures have, compared to controllable polders, a lesser effect for flood protection

27. The retention areas should remain free of large trees and bushes

28. In case of extreme flooding, these measures are not useful

29. The measures deliver an aesthetic and touristic advantage

30. Such measures cannot be used for flood protection in larger catchment areas

31. The measures are excellent in terms of nature conservation

32. Such measures only serve the objectives of the Water Framework Directive

33. Such measures are implemented for ideological reasons

34. These measures only make sense if the flood risk can be reduced by them

35. Such measures are important because solely technical flood protection is no longer sufficient

36. The measures have a potential for conflict between ecological and technical goals

37. An advantage of renaturalized waters is a positive influence on human well-being

38. An advantage of the measures compared to purely technical flood protection projects are the additional synergy benefits

39. The measures solve conflicts of objectives between the Water Framework Directive and flood protection

40. The measures offer great potential in terms of flood protection

41. The affected population prefers technical measures such as dike restorations, as these seem to offer better protection

$\begin{array}{rrr}1 & -2 & 0 \\ 0 & 2 & -2 \\ -1 & -4 & 0 \\ 0 & 3 & -2 \\ 3 & 0 & 0 \\ 0 & 1 & 3 \\ -2 & -1 & -1 \\ 2 & 2 & 1 \\ 0 & -2 & 1 \\ -1 & 0 & 0\end{array}$

$\begin{array}{lll}-1 & 0 & -3\end{array}$

$2 \quad 3 \quad 4$

$\begin{array}{lll}0 & -2 & -1\end{array}$

$\begin{array}{lll}1 & 3 & -2\end{array}$

$\begin{array}{lll}-2 & 1 & 1\end{array}$

$\begin{array}{lll}0 & 1 & -1\end{array}$

$\begin{array}{lll}-1 & -1 & 0\end{array}$

$\begin{array}{lll}0 & -1 & 1\end{array}$

$1 \quad 1 \quad-2$

$3 \quad 0 \quad 3$

$\begin{array}{lll}4 & 2 & 0\end{array}$

$\begin{array}{lll}-1 & 4 & 3\end{array}$

$\begin{array}{lll}-1 & 0 & -1\end{array}$

$\begin{array}{lll}-3 & -3 & -4\end{array}$

$\begin{array}{lll}1 & 2 & -3\end{array}$

$\begin{array}{lll}0 & -3 & 2\end{array}$

$\begin{array}{lll}-4 & -2 & 0\end{array}$

$\begin{array}{lll}-2 & -1 & -1\end{array}$

$\begin{array}{lll}1 & 0 & -2\end{array}$

$\begin{array}{lll}-3 & -1 & -1\end{array}$

222

$\begin{array}{lll}-2 & -1 & -2\end{array}$

$\begin{array}{lll}-2 & -2 & -3\end{array}$

$\begin{array}{lll}-3 & -1 & 1\end{array}$

$2-1-2$

$\begin{array}{lll}-1 & 1 & 0\end{array}$

$1 \quad 0 \quad 1$

$3 \quad 1 \quad 2$

202

$0 \quad 0 \quad 1$

$\begin{array}{lll}1 & -3 & 0\end{array}$

Note. The final statement collection of 41 statements translated from German into English and divided into 3 categories. Three-factor arrays summarizing the attitude of each viewpoint are on the right of the table. $(-4=$ most disagree, $+4=$ most agree $)$

${ }^{a}$ Viewpoint 1, The Convinced

${ }^{\mathrm{b}}$ Viewpoint 2, The Concerned

${ }^{\mathrm{c}}$ Viewpoint 3, The Evaluators 
especially, don't like the measures," states Participant 9 (MULE). Hence, The Convinced assume that local populations do not favor the measures (\#15: -2). However, "they all like it in retrospect," adds Participant 9 (MULE).

The Convinced are generally unconcerned about possible pollutants in river sediment (\#22: - 1). "The concentration of pollutants in the sediments is very low and of no concern for natural ecosystems," comments Participant 2 (MULE). This depends on the particular river though and is also "dependent on the land use after the measures implementation," according to Participant 5 (LHW). "The pollutants are usually latent and not as severe as one might think. More importantly, many pollutants are not in the sediments, but in the plant residues, which are then further distributed by fine sediments," elaborates Participant 7 (LHW).

\section{Viewpoint 2: The Concerned}

Viewpoint 2 comprises three decision-makers of lower water authorities. It has an eigenvalue of 2.9 and explains $19.35 \%$ of the study variance. The Concerned are particularly distinguished by statements $1,3,9,20$, and 39 .

Compared to The Convinced, The Concerned are worried about possible pollutants in river sediments $(\# 22:+4)$. "My county is an industrial region with big chemical plants. After every flood, the pollutants can be found on the utilized plains," explains Participant 11 (Lower Authority). Participant 15 (Lower Authority) further elaborates: "This is a local problem of the pesticide industry [...], which brings high deposits of $\beta$-hexachlorocyclohexane residues with it."

The Concerned view the measures' financing as a big issue (\#3: -4). They doubt that such measures can simply be financed by existing support programs (\#9: -2). "Financing is never easy, since political decisions are never easy," explains Participant 6 (Lower Authority). Participant 15 (Lower Authority) further specifies: "Financing the dike relocation in our county was only possible through a diffcult process, including obtaining private funding. In SaxonyAnhalt, I consider such measures to be hardly financially viable." According to The Concerned, the state generally lacks the money for implementing the measures $(\# 4:+3)$. Participant 11 (Lower Authority) explains: "We had a long list of such measures in my county and it is very sad that most of them were canceled due to a lack of financing options."

Despite these challenges, The Concerned are convinced that the measures provide effective flood protection (\#24: $-3)$. They even view the measures as equally effective to controllable polders (\#26: - 3). However, they do not believe measures would be cheaper than technical solutions in the long run $(\# 1:-2)$. This is because "dike relocation still leaves a dike to maintain, hence the maintenance stays the same," explains Participant 6 (Lower Authority). "Furthermore, the retention areas fill up with every flood by sedimentation, which has to be prevented, otherwise I lose the needed cross-section of discharged water flow", Participant 11 (Lower Authority) elaborates.

The Concerned are indecisive on whether implementing the measures is more time-consuming than for dike restorations (\#20: 0), and they have no particular opinion on whether the measures resolve conflicting objectives between the Water Framework Directive and flood protection (\#39: $0)$.

\section{Viewpoint 3: The Evaluators}

The two participants significantly loading into Viewpoint 3 work for the LHW. Viewpoint 3 has an eigenvalue of 2.5 and explains $16.86 \%$ of the study variance. In contrast to The Concerned, The Evaluators doubt the effectiveness of the measures. The Evaluators are particularly distinguished by statements $6,11,19,21$, and 29 .

The Evaluators do not think the measures should be prioritized and that they should always be evaluated in comparison with other flood protection options $(\# 19:-2)$. "These measures should not be given preferential, but equal treatment compared to other measures because they each address different targets," states Participant 13 (LHW). With respect to implementing the measures, The Evaluators strongly emphasize the importance of actively involving the population (\#12: +4$)$. "Only proper communication and information enables the implementation of these measures, otherwise it leads to considerable resistance. The earlier the people are involved, the easier it is," says Participant 3 (LHW). With suitable communication, The Evaluators do not foresee problems for implementation stemming from dispersed land ownership (\#11: - 3). "We have adequate solutions to address these issues," Participant 13 (LHW) explains. They do think the implementation of the measures is much more time-consuming than dike restorations (\#20: $+3)$.

The Evaluators doubt that the measures improve the flood situation for downstream riparians (\#25: - 3). In their judgement, polders are better $(26:+2)$. Similar to The Concerned, The Evaluators regard possible pollutants in river sediments as problematic (\#22: +3). The Evaluators see no aesthetic or touristic benefit in the measures (\#29: -2). They disagree that the measures are implemented for ideological reasons (\#33: - 3). "At the technical level of flood protection, ideological reasons do not play a role, nor should they. What matters are the hydraulics, and the costs must be kept within limits" says Participant 13 (LHW). Therefore, and in contrast to the other viewpoints, The Evaluators consider it of utmost importance that environmental and resource costs are taken 
into account for a cost-benefit analysis of the measures (\#6: $+3)$.

\section{Points of consensus}

The results show that there are eleven statements, on which the majority of participants of this study agree. These are statements $8,12,17,18,24,30,31,32,33,35$, and 40 .

The decision-makers agree upon the importance of including all stakeholders throughout the planning process of the measures (\#12: $+2,+3,+4)$. "Without preliminary work with the local population, nothing gets done," commented Participant 12 (LHW). Decision-makers also think that solely technical flood protection is no longer sufficient $(\# 35:+2,+1,+2)$ and that the measures are outstanding in terms of nature conservation $(\# 31:+2,+2,+2)$. There is also unanimity that the measures are not being implemented solely for ideological reasons (\#33: $-2,-2,-3)$ or the water framework directive (\#32: $-2,-1,-2)$. Additional benefits going beyond flood protection, such as nature conservation, deliver important arguments to justify the funding of the measures $(\# 8:+2,+2,+1)$. The participants think the measures provide effective flood protection (\#24: -3 , $-3,-4)$, particularly in large catchment areas (\#30, -3 , $-1,-1)$, which "under appropriate conditions [...] last forever," (Participant 4, Lower Authority). The decisionmakers are undecided on whether the implementation of the measures is dependent on committed individuals or not (\#18: $0,-1,1)$. Decision-makers also believe that the presence of hydropower or sewage treatment plants does not threaten the measures' implementation (\#17: $-1,-1,0$ ), a point of concern expressed in the interviews preceding this study.

\section{Distinguishing points}

The results show that there are seven statements, on which the participants of this study disagree. These are statements 2, 4, 14, 25, 26, 27 and 34.

The participants disagree on whether there is a lack of reliable data to evaluate the economic efficiency of the measures (\#2: $0,+2,-2)$. Whereas The Convinced have a neutral position toward the matter as "Economic efficiency in the sense of sustainability has never been investigated in this way" (Participant 7, LHW) The Concerned and The Evaluators are split on whether there is reliable data available.

Whether the state lacks the money to implement such measures (\#4: $0,+3,-2)$ is also disputed. The Convinced argue that "money is a matter of priorities not of abundance," (Participant 5, LHW). The Concerned believe that "the state lacks the money. It is dependent on co-financing from the federal government and the EU," (Participant 6, Lower Authority). The Evaluators are certain that financing the measures is not a problem at all since adequate funds are available. "Flood protection is not a matter of money, but effectiveness" says Participant 3 (LHW).

Further disagreement centers on whether the main problem with such measures is the availability of land $(\# 14:+1$, $+3,-2)$. The Convinced and The Concerned agree, but with different emphases. "When EU funding is used, we can't spend more than 10\% for acquiring land," says Participant 12 (LHW). The Evaluators oppose. Participant 3 (LHW) says: "We have tools within the land reallocation procedure to solve this, and money solves many problems".

Whether the measures improve the flood situation for downstream riparians $(\# 25:+1,+2,-3)$ polarizes even members of The Convinced. Participant 9 (MULE) argues that "there is a suction effect upstream only in close proximity of the measures, but not downstream" while Participant 12 (LHW) says "depending on the size of the measure, an improvement in the discharge conditions for the downstream riparians can be observed." The Concerned are certain that the measures do improve the situation for downstream riparians. The Evaluators on the other hand believe that "from a purely technical point of view, dike relocation functions upstream and flood polders downstream. A polder cuts the flood wave so that the people downstream get the benefit. With dike relocation, the water simply flows into the retention space, which means that it is only beneficial for upstream riparians" (Participant 3, LHW).

Controversial opinions also arise on whether "the measures have a lower effect for flood protection, compared to controllable polders" (\#26: 0, $-3,+2$ ). The Convinced again have "two hearts beating in a chest. Polders, for the protection of the people, and dike relocation for protecting the environment," says Participant 9 (MULE). The Concerned laud the effectiveness of the measures. "Depending on the size, polders are often not better than dike relocations" says Participant 15 (Lower Authority). The Evaluators promote the effectiveness of polders over the measures. "A polder effectively cuts the flood wave, so that the people downstream get the benefit" (Participant 3, LHW).

Views are divided over whether "the retention areas should remain free of large trees and bushes" (\#27: -4 , -2, 0). The Convinced reject this statement. "Bushes have a very positive effect since they slow down the runoff," says Participant 7 (LHW). "There are only a few places where this is a problem, e.g., city locations or constrained areas," adds Participant 1 (Biosphere Reserve Administration). The Concerned are more moderate. "Big trees do not pose a problem. The problem is when afforestation or planting occurs, which really hinders the runoff' argues Participant 6 (Lower Authority). Participant 11 (Lower Authority) says "this is a very hot topic, I personally disagree with the statement, but I know that there are other opinions as well." The Evaluators are undecided since, according to Participant 13 
(LHW), "large trees are not a problem, extensive bushes, however, are."

Disagreement is also documented on whether these measures only make sense if the flood risk can be reduced by them (\#34: - 3, - 1, +1). The Convinced disagree "because sometimes it can also make sense for reasons of nature conservation alone" (Participant 12, LHW). The Concerned agree with The Convinced to a certain extent. "The measures make sense, even if they do not reduce the flood risk" says Participant 11 (Lower Authority). The Evaluators think that the measures only make sense if the risk of flooding is reduced significantly.

\section{Discussion}

We identified three viewpoints that reflect decision-makers attitudes toward dike relocation with floodplain restoration in Saxony-Anhalt. The analysis further revealed consensus and disagreement between them, which allows us to draw conclusions on what decision-makers believe are barriers to successful implementation.

The first viewpoint, The Convinced, comprises decisionmakers with a positive attitude toward the measures. This perspective is grounded in the expected multifunctional outcomes and synergies with objectives other than flood protection. In their opinion, synergies and ecological co-benefits make the measures advantageous over purely technical flood protection measures. While the costs for planning and building technical measures are high, they believe that emphasizing NWRM might come at an even higher cost and effort. However, they believe that the multiple benefits outweigh the additional resources required and that these benefits are an excellent selling point for funding.

The second viewpoint, The Concerned, is skeptical whether the current funding schemes and institutional support networks are sufficient to realize these large-scale measures. Generally, they are in favor of the measures and do not doubt their effectiveness. They believe that the measures are as effective as actively managed polders, provide benefits to upstream and downstream users, increase ecosystem resilience and contribute to nature conservation. All the benefits, however, do not outweigh the perceived obstacles. These obstacles reflect experiences and expectations related to implementation failure associated with a lack of funding, insufficient data available to measure efficiency, and the limited availability of land.

The third viewpoint, The Evaluators, take a neutral perspective in which dike relocation with floodplain restoration need to prove their contextual effectiveness and efficiency relative to all other available measures. While The Convinced and The Concerned believe that increasing retention space also improves the situation downstream, The Evaluators do not share that position. They are generally less critical regarding potential barriers such as funding, land availability and stakeholder opinion. They emphasize the importance of involving those who are affected by measures' implementation. Their understanding of active stakeholder involvement is, however, unclear. The Evaluators viewpoint is indicative for representatives of the LHW, a subordinate state authority of the Saxony-Anhalt Ministry for Environment, Agriculture and Energy. As members of a subordinate unit of the ministry, we expected them to follow the ministry's three-pillar agenda for engaging the public. The agenda consists of informative, consultative, and cooperative participation (MULE 2020b).

Across the three viewpoints, we found a general agreement among decision-makers that the measures provide co-benefits and adequate flood protection. There is, however, some dispute about the size and direction of the effect. General disagreement exists about whether the measures benefit downstream riparians, upstream riparians, or both. The converging opinions on the effectiveness of the measures are consistent with scientific findings (e.g., Grossmann et al. 2010; Kok and Grossmann 2010; Klijn et al. 2018; Ruangpan et al. 2020). It is surprising that decision-makers generally agree about the measures' effectiveness despite the uncertainty pinning down the measures' concrete effect size in hydrological models (Busch and Hammer 2006). Studies assessing the acceptance of natural flood management measures among different stakeholder groups found similar results for public sector representatives and academics (Iacob et al. 2014; Wilkinson et al. 2019; Bark et al. 2021). The positive evaluation of effectiveness in our sample may depend on the specific context of our study, where decision-makers are already familiar with dike relocation and floodplain restorations. In consequence, they might have gained positive experiences regarding the effectiveness of the measure. This is in line with Venkataramanan's et al. (2020) findings that the willingness to implement GI varies and strongly depends on context.

The expected co-benefits for nature conservation and the Water Framework Directive seem to be critical arguments to justify the measures. This may be explained by institutions in place for the synergistic implementation of the Water Framework Directive and the Floods Directive in the German states (LAWA 2013). Also, funding requirements of the federal government's National Flood Protection Program may influence the focus on co-benefits and synergies. Positive scores for effectiveness and synergies with the Water Framework Directive, nature conservation and climate change mitigation are criteria for measures to receive funding through the National Flood Protection Program (LAWA 2014). 
While other studies found that decision-makers lack knowledge on NbS co-benefits (Wells et al. 2020; Solheim et al. 2021), our findings cannot confirm these results. Decision-makers are aware of NbS co-benefits, although not of the full range of co-benefits. As in other studies, we find a strong focus on functional benefits such as nature conservation and flood protection (Venkataramanan et al. 2020). However, synergistic effects of dike relocation with floodplain restoration need not be limited to ecological aspects but can also create benefits for tourism or provide other ecosystem services (Brouwer and van Ek 2004; Posthumus et al. 2008; Schindler et al. 2014; Klijn et al. 2018). Regarding these types of co-benefits, the three viewpoints are relatively indifferent. Only The Evaluators stand out by denying that the measures deliver such touristic benefits. To implement $\mathrm{NbS}$ in practice, their co-benefits should be stressed and communicated (Han and Kuhlicke 2019; O'Donnell et al. 2020). Especially, decision-makers need to be more informed.

The decision-makers' perception of benefits for flood risk reduction and co-benefits for nature conservation seems to shape their attitudes toward dike relocation with floodplain restoration. Once decision-makers acknowledge these cobenefits, they tend to hold a positive attitude toward the $\mathrm{NbS}$ in question (Han and Kuhlicke 2019). Attitudes toward NbS have been found to influence behavior and decision-making related to $\mathrm{NbS}$ implementation in different actor groups (Allred and Gary 2019; Santoro et al. 2019; Venkataramanan et al. 2020). For riparian landowners, attitudes and previous behavior were found to be solid predictors for implementation of buffer strips along streams (Allred and Gary 2019). It seems that a similar pattern occurs in our sample. The generally positive attitude for the measures and positive past experiences suggest high willingness for support or implementation (Ajzen 1991).

Disagreement between viewpoints is predominantly about the significance of implementation barriers such as land availability and funding. The Concerned believe that land availability and the current funding instruments are significant barriers, whereas The Evaluators disagree and do not believe so. That divide between the two viewpoints may be based on the participants' different backgrounds. The Concerned viewpoint primarily represents the opinions of county-level administrators, whereas The Evaluators viewpoint represents the opinions of state-level administrators. The responsibility for implementing large-scale measures such as dike relocation lies exclusively with state-level agencies such as the LHW. Therefore, the LHW administrators have more practical experience with different regulatory tools available for land acquisition than county-level administrators. Also, state-level authorities have more knowledge about and access to federal and EU funding, such as the National Flood Protection Program, the Joint Task for the
Improvement of Agricultural Structures and Coastal Protection, the European Agricultural Fund for Rural Development (EAFRD) and the European Regional Development Fund (ERDF) (Christ 2018; BMEL 2020). County-level administrators rely on financial resources distributed by state agencies. Nevertheless, the strong disagreement over the lack of funding between the viewpoints is surprising. Other studies find that the available budget for flood risk management measures does not seem to be a major constraint for decision-makers (Albrecht and Hartmann 2021).

Generally, limited land availability is a common constraint for implementing NWRM (BMUB 2015; Hartmann et al. 2019; Löschner et al. 2021). However, the controversy among the viewpoints focuses less on whether the land needed for dike relocation is available and more on how the land can be acquired. This is in line with findings by Albrecht and Hartmann (2021), who show that there are various instruments available for land acquisition for dike relocation, but that water management authorities have so far been reluctant to apply these instruments because of the potential administrative burden. Due to the comparatively high amount of dike relocations underway in Saxony-Anhalt, we believe that decision-makers in the state are less reluctant to apply land acquisition measures (MULE 2020b). The state also has more favorable conditions that reduce the administrative burden for agencies when exercising pre-emption rights in land acquisitions (Albrecht and Hartmann 2021).

Compared to other methods, Q-methodology allowed us to collect critical expert reflections upon the debate on using dike relocations with floodplain restoration for flood prevention and at the same time quantify their viewpoints, which were supported by the qualitative interview data.

However, some limitations need to be noted regarding the present study. While Q-methodology is suitable for identifying prevailing viewpoints and attitudes among a selected target group, the results do not allow conclusions about the distribution of viewpoints among the targeted group. Also, the scope of the results is mostly case study dependent, as the quantified attitudes are driven mainly by stakeholder experience. Therefore, the results only reflect the attitudes of decision-makers from Saxony-Anhalt in Germany.

Even though the participant sample is not representative for Germany, the selected statements are. The statements were developed based on semi-structured interviews with flood risk management experts from different German states. Therefore, we assume that the statements reflect the full breadth of the debate and are therefore relevant for all decision-makers in the field in Germany. Despite Saxony-Anhalt being a pioneer state in applying these measures, possibly implicating a certain bias, different viewpoints indicating a nuanced spectrum of scepticism was documented. The "pioneer" effect may be visible in the distribution of participants between the three viewpoints. Seven out of 15 participants 
are assigned to the viewpoint "Convinced," only three and two are assigned to "Concerned" and "Evaluators." It is true that including participants from other states in the sample would change the distribution of participants between viewpoints, and new categories might occur.

The different governance systems of flood management in Germany and other EU countries suggest that a similar study would reveal further or different viewpoints of decision-makers, which calls for further research in the field. The study is further limited by only addressing a subsection of $\mathrm{NbS}$ in flood protection. The ongoing discussion and different interpretations of the term did not allow us to ask decision-makers specifically about NbS. Instead, dike relocation with floodplain restoration was selected as an example to serve as a known model of NbS. Therefore, it must be acknowledged that this study reveals more about decision-makers' attitudes toward familiar concepts than the term NbS.

In retrospect, the 41 statements could have been phrased more concisely to cause stronger heterogeneity among the participants. The broad consensus of this study might be due to a too gentle formulation of the statements. The unanimity complicates clear differentiation between the viewpoints. Nevertheless, Q-method proved to be a valuable tool for the extraction of opinions under the condition that the statements represent a wide range of views. Sticking to the collection of interviews, which form the basis for this study, did not generate more polarizing statements. A stronger polarization could have caused more contradicting results within the viewpoints. At times, there are diverging opinions within a viewpoint, yet the statistical results put them into the same category. On the other hand, this bias can be interpreted as typically human.

Regarding the Q-sort, we could have incorporated more statements to better understand decision-makers views on stakeholder participation and funding. For funding, we did not include information on transaction costs for information, planning and design, meetings, communication, participation processes, negotiations, conflict resolution, and implementation (Meyer et al. 2012). For stakeholder participation, we can only state that decision-makers agree on its importance, but not whether this participation goes beyond informing the stakeholders.

Finally, Q-methodology reveals prevailing attitudes among a selected group of people. It does not unveil the quantitative weighting of the observed attitudes among the examined group. For this study, the majority of the participants are The Convinced. However, this finding does not imply that most decision-makers in Saxony-Anhalt share that viewpoint. It is possible that the same study, undertaken with other participants, could have resulted in a majority of The Concerned or The Evaluators. Therefore, it would be interesting to use the results for a follow-up study to determine which of the viewpoints prevail among decision-makers in Saxony-Anhalt and the other German States.

\section{Conclusion}

This study set out to investigate administrative decisionmakers' attitudes on NbS for flood prevention in SaxonyAnhalt. To identify these attitudes, we applied Q-methodology. In our case, the previous experiences of the administration of Saxony-Anhalt with dike relocations and floodplain restoration are overall positively reflected in the attitude of the respondents towards such measures for flood risk management. We, therefore, suggest that positive experiences of decision-makers and success stories of previous $\mathrm{NbS}$ projects should be shared and integrated into future decision-making processes to encourage decision-makers of other states or EU countries taking more initiative to implement $\mathrm{NbS}$ for flood risk management. While our findings cannot be generalized beyond our case study, the study could be replicated with institutions for flood risk management in other German states or different countries and with different NbS measures. Although the decision-makers agree that the application of pure technical solutions is no longer sufficient for flood risk management, they emphasized different concerns about dike relocation and floodplain restoration. We found three significant viewpoints among the experts: (1) The Convinced, (2) The Concerned and, (3) The Evaluators. The Convinced are generally in favor of the measures, emphasizing the various benefits that justify implementation. The Concerned are worried about a lack of funding and space needed for the measures and possible pollutants on the resulting floodplains. The Evaluators call for a balanced evaluation of all available measures for planning flood prevention measures.

Our study results show that varying beliefs associated with expected outcomes and potential implementation challenges define viewpoints. We did not measure the degree of each belief on a decision-maker's willingness to implement NWRM. However, we identified potential intervention points to influence willingness to implement NWRM positively. For example, states and the federal government should address the need for county-level decision-makers to have easier access to funding for NWRM on secondand third-order waters. Also, the lack of knowledge about the land acquisition toolbox or the apprehension to use it could be addressed with targeted dissemination measures. NWRMs' position in formal evaluation processes needs to be strengthened. Therefore, well-documented demonstration projects and explorations of their outcomes in evaluation processes are necessary.

Future research could include these results into a quantitative survey to get insights on how representative they are 
for a wider group of decision-makers and distinguish the governance level of the decision-makers. Such further development of our study would be another critical step toward closing research and implementation gaps on $\mathrm{NbS}$ for flood risk management.

Acknowledgements The authors would like to thank the German Federal Ministry for Education and Research for funding the PlanSmart Research Group (Grant 01UU1601A/B) to investigate Nature-based solutions in river landscapes. Further, the authors would like to express their special thanks to all decision-makers who agreed to participate in the Q-sort Interviews.

Author contributions All authors contributed to the study conception and design. LT created the first draft of the manuscript outline, designed the Q-sort, performed the interviews, analyzed the results and contributed to writing, reviewing and editing the original draft, as well as the visualization. $\mathrm{CS}, \mathrm{MB}, \mathrm{EO}$, and $\mathrm{BS}$ contributed to the design of the Q-sort, the analysis of results, writing, reviewing and editing the original draft. All authors read and approved the final manuscript.

Funding Open Access funding enabled and organized by Projekt DEAL. The authors have no relevant financial or non-financial interests to disclose. All authors certify that they have no affiliations with or involvement in any organization or entity with any financial interest or non-financial interest in the subject matter or materials discussed in this manuscript. The authors have no financial or proprietary interests in any material discussed in this article.

\section{Declarations}

Conflict of interest The authors have no conflicts of interest to declare that are relevant to the content of this article.

Open Access This article is licensed under a Creative Commons Attribution 4.0 International License, which permits use, sharing, adaptation, distribution and reproduction in any medium or format, as long as you give appropriate credit to the original author(s) and the source, provide a link to the Creative Commons licence, and indicate if changes were made. The images or other third party material in this article are included in the article's Creative Commons licence, unless indicated otherwise in a credit line to the material. If material is not included in the article's Creative Commons licence and your intended use is not permitted by statutory regulation or exceeds the permitted use, you will need to obtain permission directly from the copyright holder. To view a copy of this licence, visit http://creativecommons.org/licenses/by/4.0/.

\section{References}

Ajzen I (1991) The theory of planned behavior. Organ Behav Hum Decis Process 50(2):179-211. https://doi.org/10.1016/07495978(91)90020-T

Albert $\mathrm{C}$ et al (2019) Addressing societal challenges through naturebased solutions: How can landscape planning and governance research contribute? Landsc Urban Plan 182:12-21. https://doi. org/10.1016/j.landurbplan.2018.10.003

Albrecht J, Hartmann T (2021) Land for flood risk managementInstruments and strategies of land management for polders and dike relocations in Germany'. Environ Sci Policy 118:36-44. https://doi.org/10.1016/j.envsci.2020.12.008
Alexy M (2013) Numerische Modelluntersuchungen zu den Auswirkungen der Deichrückverlegung Lenzen und von geplanten Vorlandanpflanzungen. Bawmitteilungen 97:73-98

Allred S, Gary G (2019) Riparian landowner decision-making in the context of flooding: an application of the theory of planned behavior. Environ Syst Decis 39(4):396-408. https://doi.org/10.1007/ s10669-019-09735-1

Aproxima, Brähler G and Hackert C (2020) aproxima/htmlq. aproxima Gesellschaft für Markt- und Sozialforschung Weimar. Available at: https://github.com/aproxima/htmlq (Accessed: 27 Nov 2020)

Armatas C, Venn T, Watson A (2017) Understanding social-ecological vulnerability with Q-methodology: a case study of water-based ecosystem services in Wyoming, USA. Sustain Sci 12(1):105121. https://doi.org/10.1007/s11625-016-0369-1

Bark RH, Martin-Ortega J, Waylen KA (2021) Stakeholders' views on natural flood management: implications for the nature-based solutions paradigm shift? Environ Sci Policy 115:91-98. https:// doi.org/10.1016/j.envsci.2020.10.018

Brillinger $\mathrm{M}$ et al (2020) Exploring the uptake of nature-based measures in flood risk management: evidence from German federal states. Environ Sci Policy 110:14-23. https://doi.org/10.1016/j. envsci.2020.05.008

Brouwer R, van Ek R (2004) Integrated ecological, economic and social impact assessment of alternative flood control policies in the Netherlands. Ecol Econ 50(1-2):1-21. https://doi.org/10. 1016/j.ecolecon.2004.01.020

Brown SR (1980) Political subjectivity: applications of Q methodology in political science. Yale University Press, New Haven

Brown SR (1993) A primer on Q methodology. Available at: https:// www.researchgate.net/publication/244998835_A_Primer_on_Q_ Methodology (Accessed: 6 May 2021)

Bund/Länder-Arbeitsgemeinschaft Wasser (LAWA) (2013) Empfehlungen zur koordinierten Anwendung der EG-HWRM-RL und EG-WRRL. Magdeburg. Available at: https://www.flussgebiete. nrw.de/system/files/atoms/files/verlinkungspapier_wrrl-hwrm-rl_ mit_anlagen.pdf

Bund/Länder-Arbeitsgemeinschaft Wasser (LAWA) (2014) 'Nationales Hochwasserschutzprogramm', p 9

Bundesministerium für Ernährung und Landwirtschaft (BMEL) (2020) 'Rahmenplan der Gemeinschaftsaufgabe „Verbesserung der Agrarstruktur und des Küstenschutzes“ 2020-2023'. Available at: https://www.bmel.de/SharedDocs/Downloads/DE/Brosc hueren/rahmenplan-2020-2023.pdf?_blob=publicationFile \&v=5 (Accessed: 10 May 2021).

Bundesministerium für Umwelt, N., Bau und Reaktorsicherheit and Bundesamt für Naturschutz (BMUB) (2015) Den Flüssen mehr Raum geben. Berlin; Bonn. Available at: https://www.bmu.de/filea dmin/Daten_BMU/Pools/Broschueren/auen_in_deutschland_bf. pdf.

Bundesministerium für Umwelt, Naturschutz und nukleare Sicherheit (BMU) (2017) Kurzinfo Hochwasservorsorge und Hochwasserrisikomanagement. Available at: https://www.bmu.de/themen/ wasser-abfall-boden/binnengewaesser/hochwasservorsorge/ (Accessed: 20 Nov 2020)

Busch N and Hammer M (2006) Modellgestützter Nachweis der Auswirkungen von geplanten Rückhaltemaßnahmen in Sachsen und Sachsen-Anhalt auf Hochwasser der Elbe. Koblenz

Cattell RB (1966) The Scree test for the number of factors. Multivar Behav Res 1(2):245-276. https://doi.org/10.1207/s15327906m br0102 10

Christ A (2018) Finanzierung von Hochwasserschutzmaßnahmen. In: Heimerl S (ed) Vorsorgender und nachsorgender Hochwasserschutz. Springer Fachmedien Wiesbaden, Wiesbaden, pp 2-7. https://doi.org/10.1007/978-3-658-21839-3_1 
Cohen-Shacham E, Walters G, Janzen C, Maginnis S (2016) NatureBased Solutions to address societal challenges. Gland. https://doi. org/10.2305/IUCN.CH.2016.13.en

Commission E (2014) EU policy document on natural water retention measures by the drafting team of the WFD CIS Working Group Programme of Measures (WG PoM). Publications Office of the European Union, Luxembourg

Da Silva JMC, Wheeler E (2017) Ecosystems as infrastructure. Perspect Ecol Conserv 15(1):32-35. https://doi.org/10.1016/j.pecon. 2016.11.005

Di Baldassarre G et al (2018) Hess Opinions: An interdisciplinary research agenda to explore the unintended consequences of structural flood protection. Hydrol Earth Syst Sci 22(11):56295637. https://doi.org/10.5194/hess-22-5629-2018

Dworak T, Görlach B (2005) Flood risk management in Europe: the development of a common EU policy. Int J River Basin Manag 3(2):97-103. https://doi.org/10.1080/15715124.2005.9635249

European Commission (2015) Towards an EU research and innovation policy agenda for nature-based solutions \& re-naturing cities: final report of the Horizon 2020 expert group on ' nature based solutions and re naturing cities' : (full version). LU: Publications Office. Available at: https://doi.org/10.2777/765301 (Accessed: 19 Nov 2020).

European Environment Agency (EEA) (2010) Mapping the impacts of natural hazards and technological accidents in Europe. Publications Office, Luxembourg (EEA Technical Report)

European Environment Agency (EEA) (2017) Climate change adaptation and disaster risk reduction in Europe. Publications Office of the European Union, Luxembourg. https://doi.org/10.2800/ 938195 (EEA report)

Faulhaber P (2013) Zusammenschau und Analyse von Naturmessdaten. Bawmitteilungen 97:109-134

Gilvear DJ, Spray CJ, Casas-Mulet R (2013) River rehabilitation for the delivery of multiple ecosystem services at the river network scale. J Environ Manage 126:30-43. https://doi.org/10.1016/j. jenvman.2013.03.026

Grossmann M, Hartje V and Meyerhoff J (2010) Ökonomische Bewertung naturverträglicher Hochwasservorsorge an der Elbe. Bonn-Bad Godesberg: Bundesamt für Naturschutz (Naturschutz und biologische Vielfalt)

Guerrin J (2015) A floodplain restoration project on the River Rhône (France): analyzing challenges to its implementation. Reg Environ Change 15(3):559-568. https://doi.org/10.1007/ s10113-014-0650-8

Guttman L (1954) Some necessary conditions for common-factor analysis. Psychometrika 19(2):149-161. https://doi.org/10. 1007/BF02289162

Han S, Kuhlicke C (2019) Reducing hydro-meteorological risk by Nature-based solutions: What do we know about people's perceptions? Water 11(12):2599. https://doi.org/10.3390/w1112 2599

Hansen R et al (2019) Planning multifunctional green infrastructure for compact cities: What is the state of practice? Ecol Ind 96:99-110. https://doi.org/10.1016/j.ecolind.2017.09.042

Hartmann T, Albrecht J (2014) From flood protection to flood risk management: condition-based and performance-based regulations in German water law. J Environ Law 26(2):243-268

Hartmann T, Slavíková L, McCarthy S (eds) (2019) Nature-based flood risk management on private land: disciplinary perspectives on a multidisciplinary challenge. Springer International Publishing, Cham. https://doi.org/10.1007/978-3-030-23842-1

Heinzelmann C, Alexy M and Montenegro H (2016) Hochwasserschutz im Einklang mit Naturschutz. Die Deichrückverlegung Lenzen an der Elbe. In: Schüttrumpf H (ed) Mobil oder Nicht-Mobil? Konventioneller und innovativer Hochwasserschutz in Praxis und Forschung, Aachen, pp 1-16
Hosseinzadehtalaei P, Tabari H, Willems P (2020) Satellite-based data driven quantification of pluvial floods over Europe under future climatic and socioeconomic changes. Sci Total Environ 721:137688. https://doi.org/10.1016/j.scitotenv.2020.137688

Iacob O et al (2014) Evaluating wider benefits of natural flood management strategies: an ecosystem-based adaptation perspective. Hydrol Res 45(6):774-787. https://doi.org/10.2166/nh.2014.184

Jongman B et al (2014) Increasing stress on disaster-risk finance due to large floods. Nat Clim Chang 4(4):264-268. https://doi.org/10. 1038/nclimate2124

Kabisch N et al (2016) Nature-based solutions to climate change mitigation and adaptation in urban areas: perspectives on indicators, knowledge gaps, barriers, and opportunities for action. Ecol Soc 21(2):art39. https://doi.org/10.5751/ES-08373-210239

Kati V, Jari N (2016) 'Bottom-up thinking-Identifying sociocultural values of ecosystem services in local blue-green infrastructure planning in Helsinki, Finland. Land Use Policy 50:537-547. https://doi.org/10.1016/j.landusepol.2015.09.031

Klijn F, Asselman N, Wagenaar D (2018) Room for rivers: Risk reduction by enhancing the flood conveyance capacity of the Netherlands' large rivers. Geosciences 8(6):224. https://doi.org/ $10.3390 /$ geosciences 8060224

Koenzen U, Günther-Diringer D and Kurth A (2021) Auenzustandsbericht 2021. 1st edn. DE: Bundesamt für Naturschutz. Available at: https://doi.org/10.19217/brs211 (Accessed: 22 Apr 2021)

Kok J-L, Grossmann M (2010) Large-scale assessment of flood risk and the effects of mitigation measures along the Elbe River. Nat Hazards 52(1):143-166. https://doi.org/10.1007/ s11069-009-9363-6

Landesbetrieb für Hochwasserschutz und Wasserwirtschaft SachsenAnhalt (LHW) (2014) Studie. Halle. Available at: https://docpl ayer.org/37337153-Studie-potenzielle-standorte-fuer-hochw asserpolder-und-deichrueckverlegungen-an-den-gewaessernelbe-mulde-saale-und-weisse-elster.html.

Löschner L et al (2021) Strategic use of instruments of land policy for mobilising private land for flood risk management. Environ Sci Policy 118:45-48. https://doi.org/10.1016/j.envsci.2021. 01.009

Meng Z et al (2018) Stormwater constructed wetlands: a source or a sink of Campylobacter spp. Water Res 131:218-227. https://doi. org/10.1016/j.watres.2017.12.045

Merz B et al (2012) HESS Opinions "More efforts and scientific rigour are needed to attribute trends in flood time series." Hydrol Earth Syst Sci 16(5):1379-1387. https://doi.org/10.5194/ hess-16-1379-2012

Meyer V, Priest S, Kuhlicke C (2012) Economic evaluation of structural and non-structural flood risk management measures: examples from the Mulde River. Nat Hazards 62(2):301-324. https:// doi.org/10.1007/s11069-011-9997-z

Ministerium für Landwirtschaft und Umwelt (MULE) (2015) Hochwasserschutzkonzeption des Landes Sachsen-Anhalt bis 2020. Magdeburg

Ministerium für Umwelt, Landwirtschaft und Energie (MULE) (2018) Mehr Raum für unsere Flüsse: 1.666 Hektar neu gewonnene Überflutungsflächen seit 1990, Landesportal Sachsen-Anhalt. Available at: https://mule.sachsen-anhalt.de/aktuelles/news-detail/news/ mehr-raum-fuer-unsere-fluesse-1666-hektar-neu-gewonneneueberflutungsflaechen-seit-1990/?tx_news_pi1\%5Bcontroller\% $5 \mathrm{D}=$ News\&tx_news_pi $\% 5 \mathrm{Baction} \% 5 \mathrm{D}=$ detail $\&$ cHash $=$ aaeca 06ddafab68b4de5e249eeff672e (Accessed: 3 Nov 2020)

Ministerium für Umwelt, Landwirtschaft und Energie (MULE) (2020a) Gewässerunterhaltung, Landesportal Sachsen-Anhalt. Available at: https://mule.sachsen-anhalt.de/umwelt/wasser/gewaesserunterh altung/ (Accessed: 20 Nov 2020)

Ministerium für Umwelt, Landwirtschaft und Energie (MULE) (2020b) Mehr Raum für unsere Flüsse: Aufgabe für Generationen. 
Magdeburg. Available at: https://hochwasser.sachsen-anhalt.de/ fileadmin/Bibliothek/Politik_und_Verwaltung/StK/Hochwasser/ Mehr-Raum-fuer-unsere-Fluesse/Broschuere/200810-Mehr_ Raum_fuer_unsere_Fluesse_web.pdf

Moosavi S, Browne GR, Bush J (2021) Perceptions of Nature-based solutions for urban water challenges: insights from Australian researchers and practitioners. Urban for Urban Green 57:126937. https://doi.org/10.1016/j.ufug.2020.126937

O'Donnell EC et al (2020) Sustainable flood risk and stormwater management in blue-green cities; an interdisciplinary case study in Portland, Oregon. J Am Water Resour Assoc 56(5):757-775. https://doi.org/10.1111/1752-1688.12854

Patt H, Jüpner R (eds) (2020) Hochwasser-Handbuch: Auswirkungen und Schutz. Springer Fachmedien Wiesbaden, Wiesbaden. https:// doi.org/10.1007/978-3-658-26743-8

Posthumus $\mathrm{H}$ et al (2008) Agricultural land use and flood risk management: engaging with stakeholders in North Yorkshire. Agric Water Manag 95(7):787-798. https://doi.org/10.1016/j.agwat. 2008.02.001

Reymann H and Eichhorn A (2019) 'Deichrückverlegung im Bereich Lödderizter Forst im Rahmen des Naturschutzgroßprojektes Mittlere Elbe'. In: Technische Universität Dresden, I. für W. und H. (ed) Komplexe Planungsaufgaben im Wasserbau und ihre Lösungen. Dresden (Dresdner Wasserbauliche Mitteilungen, 62), pp 473-482. Available at: https://henry.baw.de/bitstream/handle/20. 500.11970/106338/48_Deichr\%C3\%BCckverlegung_Reymann. pdf? sequence $=1 \&$ is Allowed $=\mathrm{y}$.

Rojas R, Feyen L, Watkiss P (2013) Climate change and river floods in the European Union: socio-economic consequences and the costs and benefits of adaptation. Glob Environ Chang 23(6):1737-1751. https://doi.org/10.1016/j.gloenvcha.2013.08.006

Ruangpan L et al (2020) Nature-based solutions for hydro-meteorological risk reduction: a state-of-the-art review of the research area. Nat Hazard 20(1):243-270. https://doi.org/10.5194/ nhess-20-243-2020

Sachsen-Anhalt (2011a) Landesrecht Sachsen-Anhalt - § 1 WasserZustVO I Landesnorm Sachsen-Anhalt I Zuständigkeit des Landesverwaltungsamtes als obere Wasserbehörde | 11 - Zuständigkeit des Landesverwaltungsamtes als obere Wasserbehörde I gültig ab: 30.12.2015. Available at: https://www.landesrecht.sachsen-anhalt. de/bsst/document/jlr-WasRabwZustVST2011V3P1 (Accessed: 19 Mar 2021)

Sachsen-Anhalt (2011b) Landesrecht Sachsen-Anhalt - Kapitel 1 WG LSA I Landesnorm Sachsen-Anhalt I Kapitel 1 - Allgemeine Bestimmungen, Behörden, Zuständigkeiten I gültig ab: 01.04.2011. Available at: https://www.landesrecht.sachsen-anhalt. de/bsst/document/jlr-WasGST2011pG1 (Accessed: 19 Mar 2021)

Sandon F, Fruchter B (1956) Introduction to factor analysis. Math Gaz 40(331):74. https://doi.org/10.2307/3610309

Santoro S et al (2019) Assessing stakeholders' risk perception to promote Nature Based Solutions as flood protection strategies: the case of the Glinščica river (Slovenia). Sci Total Environ 655:188201. https://doi.org/10.1016/j.scitotenv.2018.11.116

Sarabi et al (2019) Key enablers of and barriers to the uptake and implementation of Nature-based solutions in urban settings: a review. Resources 8(3):121. https://doi.org/10.3390/resources8 030121

Schindler S et al (2014) Multifunctionality of floodplain landscapes: relating management options to ecosystem services. Landscape Ecol 29(2):229-244. https://doi.org/10.1007/s10980-014-9989-y

Schöne J (2005) Die Landwirtschaft der DDR 1945-1990. Landeszentrale für politische Bildung Thüringen

Schulz C, Adams WM (2021) In search of the good dam: contemporary views on dam planning in Latin America. Sustain Sci 16(1):255269. https://doi.org/10.1007/s11625-020-00870-2
Schwaller G (2006) Einfluss von Maßnahmen der Gewässerentwicklung auf den Hochwasserabfluss. Dresdner Wasserbauliche Mitteilungen 32:509-516

Shafroth PB et al (2010) Ecosystem effects of environmental flows: modelling and experimental floods in a dryland river: environmental flows in a dryland river. Freshw Biol 55(1):68-85. https:// doi.org/10.1111/j.1365-2427.2009.02271.x

Solheim A et al (2021) Implementing Nature-based solutions in rural landscapes: barriers experienced in the PHUSICOS project. Sustainability 13(3):1461. https://doi.org/10.3390/su13031461

Szewczyk W et al (2018) JRC PESETA III project. Publications Office of the European Union, Luxembourg. https://doi.org/10.2760/ 514048 (JRC technical reports)

Thomas F, Knüppe K (2016) From flood protection to flood risk management: insights from the Rhine River in North Rhine-Westphalia, Germany. Water Resour Manag 30(8):2785-2800

Thorslund $\mathrm{J}$ et al (2017) Wetlands as large-scale nature-based solutions: status and challenges for research, engineering and management. Ecol Eng 108:489-497. https://doi.org/10.1016/j.ecoleng.2017. 07.012

van Buuren A et al (2018) Introducing adaptive flood risk management in England, New Zealand, and the Netherlands: the impact of administrative traditions. Rev Policy Res 35(6):907-929. https:// doi.org/10.1111/ropr.12300

Venkataramanan V et al (2020) Knowledge, attitudes, intentions, and behavior related to green infrastructure for flood management: a systematic literature review. Sci Total Environ 720:137606. https://doi.org/10.1016/j.scitotenv.2020.137606

Wamsler C et al (2017) Mainstreaming Nature-based solutions for climate change adaptation in urban governance and planning. In: Kabisch $\mathrm{N}$ et al (eds) Nature-based solutions to climate change adaptation in urban areas. Springer International Publishing, Cham, pp 257-273. https://doi.org/10.1007/978-3-319-56091-5_ 15 (Theory and Practice of Urban Sustainability Transitions)

Watts S and Stenner P (2012) Doing Q methodological research: theory, method and interpretation. 1 Oliver's Yard, 55 City Road, London EC1Y 1SP United Kingdom: SAGE Publications Ltd. https://doi.org/10.4135/9781446251911

Waylen KA et al (2018) Challenges to enabling and implementing Natural Flood Management in Scotland. J Flood Risk Manag 11:S1078-S1089. https://doi.org/10.1111/jfr3.12301

Webler T, Danielson S, Tuler S (2009) Using Q method to reveal social perspectives in environmental research, vol 54. Social and Environmental Research Institute, Greenfield, pp 1-45

Wells J et al (2020) Barriers to the uptake and implementation of natural flood management: a social-ecological analysis. J Flood Risk Manag. https://doi.org/10.1111/jfr3.12561

Wilkinson ME et al (2019) Natural flood management: small-scale progress and larger-scale challenges. Scott Geogr J 135(1-2):23-32. https://doi.org/10.1080/14702541.2019.1610571

Zabala A (2014) qmethod: a package to explore human perspectives using Q methodology. R J 6(2):163. https://doi.org/10.32614/ RJ-2014-032

Zabala A, Sandbrook C, Mukherjee N (2018) When and how to use Q methodology to understand perspectives in conservation research. Conserv Biol 32(5):1185-1194. https://doi.org/10.1111/cobi. 13123

Publisher's Note Springer Nature remains neutral with regard to jurisdictional claims in published maps and institutional affiliations. 